\title{
A Descriptive Analytical Approach of Information Technology in Educational Management in United Arab Emirates
}

\author{
Rima Shishakly \\ Ajman University of Science and Technology, \\ Ajman, United Arab Emirates
}

r.shishakly@ajman.ac.ae; rima84@hotmail.com

\begin{abstract}
In comparison to the other Arabic counties, the United Arab Emirates (UAE) has positively and effectively progressed, in a short space of time in educational innovation. A brief overview of the United Arab Emirates and the structure of the educational system will be presented and a more detailed analysis on how the usage of Information Technology in Educational Management (ITEM) has developed over a decade will be explained.
\end{abstract}

ITEM utilization has grown enormously in UAE; various modifications within the educational system have been done, specifically towards innovation, modernization and school management decentralization. Nonetheless, a certain improvement and maturity has been reached in using information technology in school management.

Two major School information systems are accredited in the UAE government (public) schools. The first School information systems (SIS) is used by the Ministry of Education (MOE), and the other, Enterprise School Information systems (eSIS) is used by Abu Dhabi the capital of UAE. The paper will focus on the SIS which is implemented recently by the MOE and then conclude the challenges, future ambitions and issues facing MOE school information systems.

Keywords: Information Technology in Educational Management (ITEM), School Information System (SIS), Enterprise Student Information System (e SIS), system utilization in UAE, Abu Dhabi Education Council (ADEC), Ministry of Education (MOE), Information Technology (IT).

\section{Introduction}

Schools, like other organization have to deal with huge amounts of data. The administrative tasks, curriculum, assessment data and staff data network has grown and the need to access this data at many physical points in the school as well as outside, has put an increase on the demand for

Material published as part of this publication, either on-line or in print, is copyrighted by the Informing Science Institute. Permission to make digital or paper copy of part or all of these works for personal or classroom use is granted without fee provided that the copies are not made or distributed for profit or commercial advantage AND that copies 1) bear this notice in full and 2) give the full citation on the first page. It is permissible to abstract these works so long as credit is given. To copy in all other cases or to republish or to post on a server or to redistribute to lists requires specific permission and payment of a fee. Contact Publisher@,InformingScience.org to request redistribution permission. school information systems (SIS) to support school daily processes.

This paper will briefly describe the structure of the government's educational system in the UAE. It will highlight the development and modification of the educational systems in the UAE, especially the move towards education decentralization. The focus will be on the School Information systems (SIS), which was implemented recently by 
MOE in the UAE. Abu Dhabi, the capital of UAE, manages the government schools via its Abu Dhabi Educational Council (ADEC). It uses eSIS to support the administrative work in the school; store and process large amounts of administrative data relating to student enrolments, students' records and achievements.

The main objectives of the paper are to introduce, describe and analyze the SIS used by the MOE and discuss the challenges facing the school information systems and the future motivations.

\section{The UAE Context}

The United Arab Emirates is a young country located on the shores of the Arabian Gulf in the Middle East. In 197, the unification of the seven emirates was established. The foundation of the federation and the economic growth enabled the country to achieve development and progress in various sectors including education. This reflects a great amount of investment and efforts to innovate the educational sectors, and use the information technology effectively and efficiently in the teaching, learning and management features. Regarding the educational system in the UAE, it is consistent across the seven emirates (Abu Dhabi, Dubai, Sharjah, Ajman, Ras Al-Khaimah, Fujairah, and Umm Al-Quwain). As a structure, it is not complex; it consists of basic school and secondary schools. At 6 years of age the student starts basic government (public) school. The student goes at the age of 4 through kindergarten to grade 12: two years is spent in kindergarten, five years at the first unit (level 1-5), four years at the second unit (levels 6-9) and three years at secondary school (levels 10-12). Schools are funded, staffed and equipped by the Union government of the UAE. Basic education is free at all levels. Education is compulsory at the first unit between the ages of 6 and 12 (MOE, 2005).

There were 475 government schools, and a total of 200,000 Students (MOE, 2005). The schools were managed by nine educational zones. Abu Dhabi educational zone, the western region educational zone, Al-Ain educational zone, Dubai educational zone, Sharjah educational zone, Ajman educational zone, Umm Al Quwain educational zone, Ras Al-Khaimah educational zone, and AlFujairah educational zone. In terms of communication and data flow between the schools and the MOE, this goes via the educational zone. The system has been centralized; likewise the use of computers for administrative applications in education reflects the attitude of centralization.

The success of the UAE's efforts and investment in the information technology infrastructure and utilization in the educational sectors lead to the rapid growth of the government schools' number which is raised to 723 schools, 262,373 students, which are educated by 22,732 teachers and 4,737 administrators (MOE, 2010).

Using technology and technology integration in education is a top priority on the list of educational objectives in the UAE. Between 1999 and 2008, significant development had taken place in the implementation of computers in the government school for supporting administrative tasks. According to the Global Information Technology Report (2010-2011), the UAE ranked $24^{\text {th }}$ among the 138 countries and took first position among the Arabic counties reflecting the success of the government's efforts in the area of education (Dutta \& Mia, 2011). Implementing school information systems enable the MOE to use Information Technology (IT) efficiently, manage and control the government schools in UAE - this was an ambition step and challenges decisions. Laudon and Laudon (2010) define implementation as the final stage of decision making, when the individual puts the decision into effect and reports on the process of the solution. Telem (1996) mentions that implementation of a school management information system (SMIS) constitutes a big challenge for schools and decision makers as well. Successful implementation according to Fung's (1995) explanation is in effect the facilitation of an integration process of the school information system by the school. 
The UAE has been motivated towards 'decentralizing' education since 2008. Education decentralization seems to be a global trend in the past decades. Astiz et al. (2002) mention that "over the past several decades, there has been a preoccupation with decentralization in the policy discourse about education, particularly among the developing nations of Latin America, South Asia, and Eastern Europe and among international developing agencies."p1. And Abu-Duhou (1999) supports the statement that the interest in decentralizing education is a worldwide phenomenon and the decentralization processes is becoming more and more common for future schools worldwide.

In general, public education is bureaucratic. Bureaucracy discourages creativity and innovation and encourages focus on fulfillment with the rules. Decentralization could provide authorization in decision making within the school management. According to Paqueo and Lammert (2000) "decentralization involves shifting management responsibilities from the central to regional or lower levels so that the center retains control." Behrman el al. (2002) mention that "decentralization of education includes devolution of authority and responsibility for schools from central to local levels, increased local financing of schools, decentralization of school functions, and reforms to be incentive structure of schools and their teachers"p.8

The emirate of Abu Dhabi, Dubai, Sharjah, and Fujairah in the UAE moved towards the decentralization of the educational system by creating education councils in those emirates; known as Abu Dhabi Education Council (ADEC), Sharjah Education council and the knowledge and humanities Authority in Dubai and Fujairah educational council. Currently, three educational Zones are merged and managed by ADEC. In particular, ADEC in (2009) involves decentralized decision making, and implements fully integrated systems named Enterprise Student Information Systems (eSIS) in order to increase efficiency and effectiveness in the school organization management, teaching, learning and provides access to the parents to track their children's' performance.

\section{Features of the School Information Systems}

One of the first 'national' computerized administration initiatives that can be identified was developed in- house by individuals in the MOE to support high school certificates and some other initial tasks. Over a decade, several systems were proposed but were not able to fully become computerized- the administrative tasks, students' enrollment, student records, staff affairs and performance tracking.

In 2009, the trend was to encourage creation and implementation of national SIS to support the government schools in the UAE. The availability of funding created significant opportunities for commercial suppliers to develop systems consistent with the nature of the government schools in UAE.

MOE endorses two major Schools Information Systems and four sub systems to support school management, staff affairs, school daily operation, and student affairs. The two major systems complemented the demand for fully computerized UAE educational system management, student registration, and students' assessment. The systems were implemented in the academic year (2010-2011) to support about 420 schools in six educational zones in the emirate of Dubai, Sharjah, Ajman, Ras Al-Khaimah, Um Al Quwain, and Al Fujairah. Those expected systems will support six educational zones in those Emirates.

The two basic systems are: Registration and Enrollment system and Examination and Assessment system.

- The Registration and Enrollment system was intended to support student registrations and enrollments in the government school in the different educational zones. The system provides fully computerized care for the students' data and 
recorders with the ability to track the student from kindergarten until the final year of school, monitor student school transformations, and other administrative resolutions.

- Examination and Assessment system supports student mark entry, examination schedule, class marking/grading and prepares general reporting, student assessment, and measures the educational performance. The objectives are controlling, improve the registration process, data flow within schools, between the ministry, educational zones and the schools to achieve efficient daily school operation, as well as tracking students performance in all the government schools in different levels within the country.

There are four other sub-systems implemented by the MOE:

- Information student System (I-SIS) assists students' education and learning. It is used for students to collaborate with each other and with the teacher. The system provides an e-gate for the students to enrich their learning, their information and allow them to communicate digitally with the courses materials. And provides access for the teachers, student and parents to monitor and follow the educational operation.

- Human Resource (HR) systems which enhance the access to senior staff, teachers, administration and secretaries and other schools' staff files to modify it and update their personal data.

- Training system, which is designed to allow physical access to all school staff members to select and direct digital register in the available training courses according to each individual's needs.

- School Organization System supports and provides access to the principals to review the historical data and forecast school needs for teachers, administrative stuff, secretaries or any other schools staff. The list can be updated and modified by schools' principals. These systems were implemented to support the educational operation in the government schools.

Regarding the further system accredited in UAE, Enterprise Student Information Systems (eSIS) which completed the implementation phases in 2011. ADEC's goals were to support decision makers, principals, vice principals, administrative staff, teachers, students and parents, health and wealth tracking, curriculum tracking, and eSIS wireless. The strategy started at the level above the individual schools but it covers three hundred schools in the three regions of Abu Dhabi. The strategic vision was to use technology to facilitate change in all the schools in the Abu Dhabi region and to provide school information systems assistance in school teaching and management. The vision was to implement well designed systems to satisfy all the stakeholders and decision makers within the educational system and to carry the innovation to the management systems from its current state to one of a high quality standard (ADEC, 2009).

The systems are being designed for the education authority in the Abu Dhabi and the Abu Dhabi region. The system was designed and integrated across a range of levels and functions to fit the requirement of large numbers of the users. Furthermore the design goal was to make the system easy to use and easy to navigate. eSIS can track the student from kindergarten till the final year of school and assist teachers, student and parents to communicate and follow the educational operation. 
eSIS consists of two phases.

- Phase one: Implemented in 2009 and defined with four major modules customized to meet Abu Dhabi's requirements. The modules are: P-12 students' demographics, school information, daily attendance, and mark entry. There were about 5000 users in 2009; principal, vice principals and the employee only. The scope of the phase one was to assist student registration from primary school to grade 12, register daily attendance enter class marking/grading and prepare general reporting. The systems applications were to store all teacher details, SMS connection, ERP interface and executive assistance.

- Phase two: Complete implementation in September 2011. The scope of this phase was to assist teachers and parents, providing wireless access to eSIS from any wireless device and obtain automated school time tables, student suspensions/ discipline, selection of gifted student and transportation. In 2010-2011 the strategy was to expand the numbers of the trained users such as teachers. There are now 12000 users trained to use the first phase and to be continuing training for the second phase. The system is going to provide a vision to be shared by all the school stakeholders. (Fung, 2001) state that the role of SIS is to support the development of a professional learning community both within and across the schools, staff development online, global collaborations on the internet and cross-cultural exchange will all become commonplace.

\section{Challenges and Future Development}

One of the major challenges that face MOE and ADEC is the training for the large numbers of users. (Tatnall, 2001) mentions that users in the school must be regarded as the most important consideration in the systems' implementation. O'Mahony, Wild, Selwood, Kraidej, and Reyes (1997) state that "problems with ITEM include use and usability, staff training, staff awareness and resistance to change" (p. 191). training of user personnel is critical. Olson (2004) mentions that poor training of users responsible for most of the problem because of user previous experiences and qualifications, diversity of response toward technology usage and training, the complexity of the system, and the variety of training methods available. Monk and Wanger (2009) agree that employees will not be productive without continuing development and training.

The goal of MOE is to provide complete training courses to accomplish full utilization of the systems. A training plan should be developed so that it includes everyone who will either support or use the MOE systems. MOE is providing continual training for all the system users by entering them in training system and registering them for several training course during the academic year. ADEC found that the solution for providing training for 12,000 system users is to provide peer training between the staff members, on line training and video training. Training is a crucial factor affecting the implementation and use of any system. Visscher and Bolemen (2001) mention that there is strong empirical evidence that user training strongly influences the degree of information system usage. Without training, the systems implementation will take longer, adaptation will be more problematic.

The critical question is if the online training course is enough to help to reach this target. It is important to keep in mind that this can only be answered based on the users' levels of eSIS utility and experience whether they be management staff, teachers, students or other stakeholders. Baldwin and Ford (1988) defined 'positive transfer' as the degree to which trainees effectively apply knowledge, skills and attitudes gained in a training context to their job. Delahoussaye et al. (2002) say that organizations that make large investments in people typically have lower employee turnover, which is associated with higher customer satisfaction and this in turn, is influenced by training and development. 
Data integration is other challenge that faces MOE and ADEC. Data integration is a vital to asset school management and decisions-makers across the different educational zones. System integration is essential in every school because it allows several features to work together, to ensure that data is entered just once and then made available to every other area of the school units or divisions. Hua and Herstein (2003) say that data integration is intended to add value to the data that are already collected and made available in variously scattered places within the same system. Breiter et al. (2008) agree that " within integrated school Management information system (ISMIS) and different scopes of the school management and administration are joined and prepared for the different stakeholders" (p.5).

The crucial question is how far are the MOE and ADEC systems providing flexible technology, and user-friendly interfaces, quick and convenient access to data, improved quality and comprehensiveness of data, consistency and reduction of costs of data collection, storage and processing? Data integration is one of the most important SIS development strategies. It means that data from multiple sources, multiple years and multiple levels (student, teacher, or school level) can be linked, integrated, or merged.

\section{Conclusion}

In the UAE, it is apparent that considerable progress has been made in implementing SIS in schools. The experience is promising. And without effective system management, efficient training, and skills development, this could lead to time-consuming, system failure for MOE and ADEC. On the other hand, MOE and ADEC are facing extremely challenging circumstances in the strategic decisions that they took. Based on that issue, it may be too is early to evaluate the experience even though certain feedback has been collected about system functioning and user satisfaction of eSIS in ADEC's school information systems. There must be continual research in this topic concerning system utility and user training.

\section{References}

Abu-Duhou, I. (1999). School-based management. Fundamental of Education Planning, No 62 in the series. Paris: UNESCO.

Abu Dhabi Education Council. (2009). Enterprise School Information Systems (eSIS).

Astiz, M. F. ,Wiseman, A. W., \& Baker, D. P. (2002). Schooling towards decentralization: Consequences of globalization for curricular control in national education systems. Comparative Education Review, $1(1), 66-86$.

Baldwin, T. T., \& Ford, J. K. (1988). Transfer of training: A review and directions for future research. Personnel Psychology, 41, 63-105.

Behrman, J. R, Deolakira, A. B, \& Soon, L. Y. (2002). Conceptual issue in the role of education decentralization in promoting effective schooling in Asian developing countries. ERD working paper series No 22. Economic and Research Department. September 2002.

Breiter, A., Stauke, E., \& Lange, A. (2008). School information systems and data based decision making. Berlin: Peter Lang.

Delahoussaye, M., Ellis, K., \& Bolch, M. (2002). Measuring corporate smarts. Training Magazine, August, 20-35.

Dutta, S., \& Mia, I. (2011). The global information technology report 2010-2011. INSEAD

Fung, A. C. W. (1995).Managing change in ITEM. In B. Barta, M. Telem, \& Y. Gev (Eds), Information Technology in Educational Management (pp 37-45). London: Chapman \& Hall. 
Hua, H., \& Herstein, J. (2003). Education and Management Information System (EMIS): Integrated data and information systems and their implications in education management. Paper presented at the Annual Conference of Comparative and International Education Society, New Orleans, LA, USA

Lange, A., \& Breiter, A. (2009). Bringing order into chaos. Building an integrated school information system - A case study from Germany. In C. O'Mahony, A. Finegan, A. J. Visscher, \& A. Tatnall (Eds.), Evolution of information technology in educational management. Springer.

Laudon, C. K, \& Laudon, J. P. (2010). Management information systems. Managing the digital firm (11th ed.). Pearson.

Ministry of Education. (2005). Research and development IT in school management. Official document/ MIS department. Ministry of Education, Dubai

Ministry of Education. (2010). The strategic vision 2010. Official Documents. Ministry of Education in United Arab Emirates, Dubai.

Monk, E., \& Wagner, B. (2009). Concept in enterprise resource planning (3rd ed.). Boston: Cengage Learning.

O’Mahony, C. D, Wild, P., Selwood, I. D., Kraidej, L., \& Reyes, M. G. (1997). Evaluation strategy for ITEM quality. In A. C. W. Fung, Information technology in educational management for the school of the future. Kluwer Academic.

Olson, D. L. (2004). Managing issues of enterprise resource planning systems. MacGraw-Hill.

Paqueo, V.. \& Lammert, J. (2000). Decentralization \& school-based management resource kit. World Bank.

Telem, M. (1996). Recently MIS implementation in school: A system socio-technical framework. Computers \& Education, 27(2), 85-93.

Tatnall. A. (2001). Synthesis of Experience, Research and Future Perspectives on Computer-Assisted School Information Systems. In A. Visscher, P. Wild. \& A. C. W. Fung (Eds.), Information technology in educational management. Kluwer Academic Publisher.

Visscher, A. J., \& Bloemen, P. P. M. (2001). School managerial usage of computer-assisted school information systems: A comparison of good practice and bad practice school. In P. Nolan \& A. Fung (Eds.), 2001 Institutional improvement through information technology in educational management. London: Kluwer.

\section{Biography}

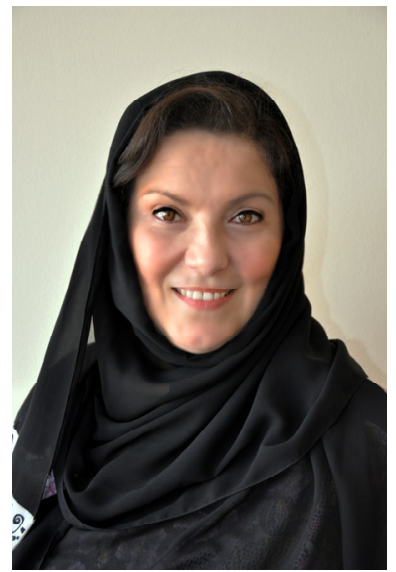

Dr. Rima Shishakly completed her MBA in Brussels-Belgium, before obtaining her $\mathrm{PhD}$ in Management Information Systems from the University of Manchester, United Kingdom and began teaching at the University of Sharjah-United Arab Emirates (UAE). Now she is a professor at Ajman University of Science and Technology (AUST) in UAE. Her interests include e-commerce, e-business, and Information Technology in Management. She developed different research papers in the field Information Technology in Educational Management (ITEM), and Enterprise Resource planning (ERP) 